\title{
Cordonnier Grade 1 Viral Complication, Asymptomatic Cytomegalovirus Infection
}

National Cancer Institute

\section{Source}

National Cancer Institute. Cordonnier Grade 1 Viral Complication, Asymptomatic

Cytomegalovirus Infection. NCI Thesaurus. Code C138308.

Any asymptomatic cytomegalovirus infection. 